\title{
Confirmatory Factorial Analysis to Validity a Theoretical Model to Measure Attitude toward Statistic

\author{
Milka Elena Escalera-Chávez
}

\author{
Multidisciplinary Unit Middle Zone, \\ Universidad Autónoma de San Luis Potosi SLP-México \\ E-mail:milkaech@uas/p.mx
}

Arturo García-Santillán

Administrative-Economic Research Center, Universidad Cristóbal Colón, Ver. México E-mail: agarcias@ucc.mx

\section{Francisco Venegas-Martínez}

Escuela Superior de Economía del Instituto Politécnico Nacional (ESE-IPN), México E-mail: fvenegasIII@yahoo.com.mx

Doi:10.5901/mjss.2014.v5n1p569

\begin{abstract}
In this study was examined whether the constructs: usefulness, motivation, likeness, confidence and anxiety influence the student's attitude towards statistics. Were surveyed 326 students in the public university using the questionnaire proposed by Auzmendi (1992). Data analysis was performed by structural equation model AMOS software. The results do not support the model proposed by Auzmendi of five components. The results suggest that the data are adjusted to only two components, namely: likeness and confidence. About global adjusted of model, the quality measures of absolute fit show: Chi-square statistic $(15.123, d f=8$ probability level $=0.057)$ is significant, and all indexes showed a satisfactory fit. The values of GFI (0.985), AGFI (0.960) and RMSA (.052) are satisfactory because their values tend to 1 and are > of .5. The attitude towards statistics on students in the Universidad Politécnica de Aguascalientes, is a friendly attitude, which reveals that on this institution the subject Statistics is focused towards the practical application
\end{abstract}

Keywords: Components, usefulness, motivation, likeness, confidence and anxiety

\section{Introduction}

Continuing with empirical studies performed by García-Santillán, Venegas-Martínez y Escalera-Chávez (2013), now we carry out a study in a public university in order to measure the students attitude toward statistical trough modeling with structural equation, all this, in order to identify if the components of model proposed by Auzmendi (1992) could be show an alternative model.

\subsection{Background of case}

The results obtained by Garcia et al (2013) show, that there are two factors that explain the phenomenon of study, and these are: the favorable attitude towards statistics that compose three factors (usefulness, anxiety, confidence) and unfavorable attitude towards statistics composed of two factors (anxiety and motivation).

Furthermore, these results show that when students see the usefulness of statistics in the professional field, all this makes that they like the topic, which gives them confidence to learn, however if not are motivated, them can cause anxiety.

These findings are consistent with those reported by Auzmendi [1992] who pointed out that the factors of greater influence are those related to motivation, liking and utility. Furthermore, there is another empirical referent, the work of Mondejar et al [2008] who suggest that the anxiety and nervousness have an influence on the student's attitude towards 
the field of statistics.

They conclude with some recommendations on the possible implementation of measures that integrate the motivational aspect, which could avoid the anxiety of the students and with this, strengthen strategies of teaching statistics in every area of study chosen by the student in order to improve the attitude towards statistics taking into account the impact that may generate in the process of learning of this course as refers Schutz, et al [1997].

Furthermore, it is necessary that teachers who "teach the class" should have statistical knowledge on the subject and the capacity of motivate students, resulting in greater fruit in the teaching-learning process.

\section{Literature Review}

In the review of literature about this subject, Blanco (2008) it carried out a critical review about students' attitude toward statistics. In his study described some inventories test that measure specifically the students' attitude statistic. In his study refer the research of Glencross y Cherian (1992) who cited the most important studies in the Anglo-Saxon context such as: Statistics Attitudes Survey- SAS Roberts y Bilderback (1980), Attitudes toward Statistics- ATS Wise (1985), Statistics Attitude Scale McCall, Belli y Madjini (1991), Statistics Attitude Inventory (Zeidner, 1991), Students'Attitudes Toward Statistics Sutarso (1992), Attitude Toward Statistics Miller, Behrens, Green y Newman (1993), Survey of Attitudes Toward Statistics -SATS Schau, Stevens, Dauphinee y Del Vecchio (1995), Quantitative Attitudes Questionnaire Chang (1996) among other.

In summary, one of the first operative definition and measure about attitude toward statistics is the test of Roberts and Bildderbach (1980) denominated Statistics Attitudes Survey (SAS). It's considered the first measure about construct called "Attitude toward statistics" in fact, was made with the intention of providing a focused test in statistics field in order to measure this subject, from the tradition and professional work of students (García et al, 2013).

Continuing with the theoretical explanation of this subject, Mondejar, Vargas and Bayot, (2008) developed a test based on the methodological principles of Wise (1985) attitude toward statistic (ATS) and scale attitude toward statistics (SATS) of Auzmendi (1992). Mondéjar et al (2008) describe the psychometric properties of this new scale to measuring attitude toward statistics. With this result they obtained a tool to measuring or quantifying the students' affective factors. This scale may show the level of nervousness-anxiety and other factors such a gender. All this could affect students' attitude like say Phillips (1980), he refers that the students' attitude can suppose an obstacle or constituted and advantages for their learning.

Roberts y Saxe (1982); Beins (1985); Wise (1985); Katz y Tomezik (1988); Vanhoof et al (2006); Evans (2007) showed the relationship between attitude toward statistic and academic outcomes or the professional use of this tool. They have confirmed the existence of positive correlation between students' attitudes and their performance in this area. In Spain, Auzmendi (1992), Sánchez-López (1996) y Gil (1999) have confirmed the existence of positive correlation between students 'attitudes and their performance.

Furthermore, important arguments are exposed by Auzmendi (1991), Gal \& Ginsburg (1994) and Ginsburg \& Schau (1997) about students' attitude statistic; they refer that the attitude toward statistic is an essential component of the background of student with which, after its university training, may carry out academic and professional activities. Other studies have attempted to measure the work underlying this issue: e.g. scale ATS proposed by Wise (1985) and the scale of Auzmendi (1992) collected the most relevant characteristics of the students regarding their attitude towards statistics, his difficulty with the mathematical component and prejudice before the subject. Of this, have derivate works such as Elmore and Lewis (1991) and Schau et al (1995). About the scale ATS proposed by Wise, is structured of 29 items grouped in two scales, one that measures the affective relationship with learning and cognitive measures the perception of the student with the use of statistics.

Mondéjar et al (2008) refer to that initially validation was based on a sample very small, and was with subsequent studies such as Mondejar et al (2008) or Woehlke (1991) who's corroborated this structure, and the work of Gil (1999) choose to use an structure with five factors: one of the emotional factor and the remaining four factors related cognitive component.

Finally, and considering all arguments mentioned above as a theoretical framework in order to understand the attitude toward statistical in undergraduate students: and considering that this study seeks to find answers to the research questions about of attitude towards statistic in undergraduate students, we use the scale SATS proposed by Auzmendi, thus, it set the following: 


\subsection{Question, objective and hypothesis}

$R Q_{1}$. What factors can help explain the attitude toward statistic in college students?

So1. Develop a theoretical model that integrates the factors that explain attitude toward statistic.

$\mathrm{So}_{2}$. Evaluate the model using the elements of each factor.

So3. Evaluate the adjusted model.

$\mathrm{Hi}_{1}$ : There are factors that can help explain the attitude toward statistic in undergraduate students

\section{Research Methodology}

\subsection{Kind of study, population, instrument}

This study is non-experimental, transversal and confirmatory, because we need to know the attitude toward statistics in colleague students in private university. The sample was selected for the trial of non-probability sampling. Were surveyed 326 students at Universidad Politécnica from several profiles; Business and management, Mechatronic engineering, Industrial engineering, Strategic systems of information engineering. The selection criteria were to include students who have completed at least one field of statistics in the degree program they were studying and were available at the institution to implement the survey. The instrument used was a survey of attitudes toward statistics or SATS.

The scale SATS proposed by Auzmendi (1992) indicates the existence of five factors: usefulness, anxiety, confidence, pleasure and motivation. The usefulness factor indicators are: Item 1, 6, 11, 16, 21; anxiety factor indicators are: Item 2, 7, 12, 17, 22; the confidence factor are: items 3, 8, 13, 18, 23; likeness factor indicators are: Item 4, 9, 14, 19, 24.

Finally indicators belonging to motivational factor are: items $5,10,15,20,25$. The diagram of factors sequences is shown in figure 1 and the table 1 described the indicators, definitions and codes/items (García-Santillán, Moreno, Carlos, Zamudio and Garduño (2012).

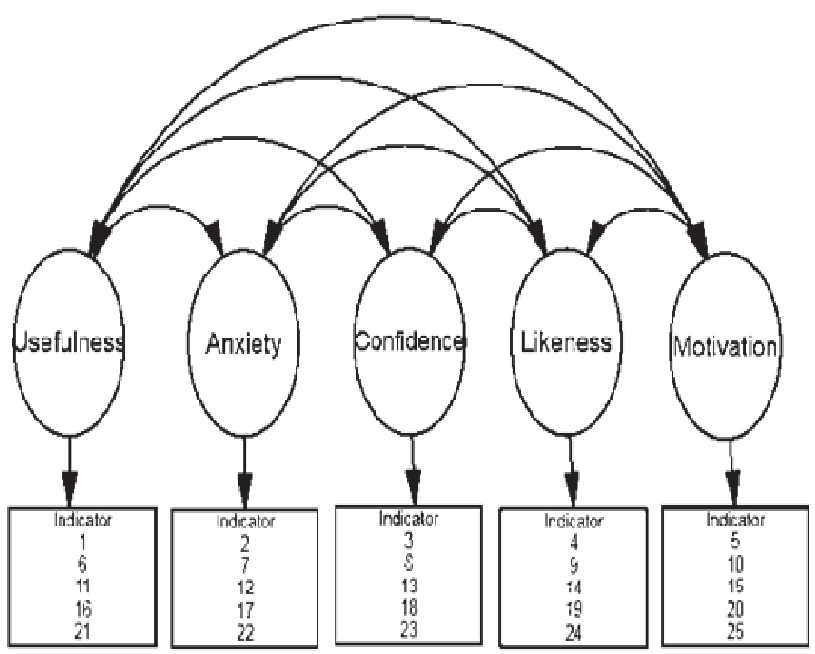

Figure 1: Sequence Diagram

Table i. Scale factors attitude towards statistics

\begin{tabular}{|c|l|c|}
\hline \multicolumn{1}{c|}{ Indicators } & \multicolumn{1}{c}{ Definition } & Code/items \\
\hline Likeness & Refers to the liking of working with statistics. & $4,9,14,19$ and 24 \\
\hline Anxiety & Can be understood as the fear the students manifests towards statistics. & ANX \\
\hline
\end{tabular}




\begin{tabular}{|c|l|c|}
\hline & & $2,7,12,17$ and 22 \\
\hline Confidence & Can be interpreted as the feeling of confidence of the skill in statistics. & $\begin{array}{c}\text { CNF } \\
3,8,13,18 \text { and } 23\end{array}$ \\
\hline Motivation & What the student feels towards the studying and usefulness of statistics. & $\begin{array}{c}\text { MTV } \\
5,10,15,20 \text { and } 25\end{array}$ \\
\hline Usefulness & It is related to the value that a student's gives statistics for its professional future. & $\begin{array}{c}\text { USF } \\
1,6,11,16 \text { and } 21\end{array}$ \\
\hline
\end{tabular}

Source: take from García et al (2012)

\subsection{Statistical procedure}

If we considering that the Structural equation modeling (SEM) is a technique for testing hypothesized relationships among variables by estimating a series of separate, still interdependent, multiple regressions simultaneously, therefore the use of SEM is considered appropriate for this research due to its great potential for extending the theory development and its capability of simultaneously assessing the multiple and interrelated dependence relationships (Gefen, Straub and Boudreau (2000).

Furthermore, this study integrates latent variables representing unobserved concepts, which is possible by using SEM due to its ability to include latent variables while accounting for measurement error in the estimation process (Hair, et al. 1998). If we start from the objectives that were set; So ${ }_{2}$ Evaluate the model using the elements of each factor and $\mathrm{SO}_{3}$ Evaluate the adjusted model, therefore this study uses two-step approach to SEM; a measurement model and a structural model.

A measurement model is estimated followed by an estimation of structural model. The measurement model involves in development a confirmatory factor analysis (CFA) that allows to assessing the contribution of each indicator variable and for measuring the adequacy of the measurement model.

The measurement model involves in conducting a confirmatory factor analysis (CFA) for assessing the contribution of each indicator variable and for measuring the adequacy of the measurement model.

- The first step in analyzing CFA is the model specification.

- The second step is an iterative model modification process for developing a more parsimonious set of items to represent a construct through refinement and retesting.

- The third step is to estimate the parameters of the specified model.

- The overall model fitness is evaluated by several measures of goodness of test to assess the extent to which the data supports the conceptual model.

Various Goodness of Fit (GOF) measures used in this study include the likelihood ration chi-square $\left(X^{2}\right)$, the ratio of $X^{2}$ to degrees of freedom ( $X^{2} / \mathrm{df}$ ), the Goodness of Fit Index (GFI), the Adjusted Goodness of Fit Index (AGFI), the Root Mean Square Error of Approximation (RMSEA) and Tucker-Lewis (TLI) index (Hair, et al. 1998).

The guidelines for acceptable values for these measures are discussed below. A non-significant $X^{2}(p>0.05)$ is considered to be a good fit for the $X^{2}$ GOF measure. However it is believed that this does not necessarily mean a model with significant $X^{2}$ to be a poor fit. As a result consideration of the ratio of $X^{2}$ to degrees of freedom $\left(X^{2} / \mathrm{df}\right)$ is proposed to measure as an additional measure of GOF. A value smaller than 3 is recommended for the ratio ( $\left.X^{2} / \mathrm{df}\right)$ for accepting the model to be a good fit (Chin, et al, 1995).

The GFI is developed to overcome the limitations of the sample size dependent $X^{2}$ measures as GOF (Joreskog, et al. 1993). A GFI value higher than 0.9 is recommended as a guideline for a good fit. Extension of the GFI is AGFI, adjusted by the ratio of degrees of freedom for the proposed model to the degrees of freedom for the null model. An AGFI value greater than 0.9 is an indicator of good fit (Segars, et al 1993).

RMSEA measures the mean discrepancy between the population estimates from the model and the observed sample values. RMSEA < 0.1 indicates good model fit (Browne, et al. 1993; Hair, et al. 1998). TLI, an incremental fit measure, with a value of 0.9 or more indicates a good fit (Hair, et al. 1998). Except for TLI, all the other measures are absolute GOF measures. The TLI measure compares the proposed model to the null model.

Based on the guidelines for these values, problematic items that caused unacceptable model fit were excluded to develop a more parsimonious model with limited number of items. 


\section{Finding and Discussion}

At first instance the assessment for adjusting the model set was made, because the model set represents the degree that specific indicators represent the constructs assumptions, to this effect measures absolute fit: Chi-square, GFI, RMSEA were used, incremental fit measures (TLI and NFI) and measures for adjustment Parsimony (AGFI), the values are shown in the table 2.

Table 2. Measures Goodness of Fit: Revised model and null

\begin{tabular}{lc}
\hline Chi-square $\left(X^{2}\right)$ & 1880.078 \\
Degree of freedom (df) & 144 \\
Significance level (sig.) & 0.000 \\
Normed Chi-square ( $\left.X^{2} / g I\right)$ & 13.056 \\
Goodness of Fit Index (GFI) & 0.677 \\
Adjusted Goodness of Fit Index (AGFI) & 0.574 \\
Root Mean Square Error of Approximation (RMSEA) & 0.193 \\
Tucker Lewis Index (TLI) & 0.354 \\
Normed Fit Index (NFI) & 0.441 \\
\hline
\end{tabular}

Source: own

It can be seen that each of the values, although tends to one, these are low, because if we consider what it says Hair (1998) the recommended values are values of .90 or higher, so it is necessary to modify the model through the modification indexes, therefore the modified model is presented in Figure 2.

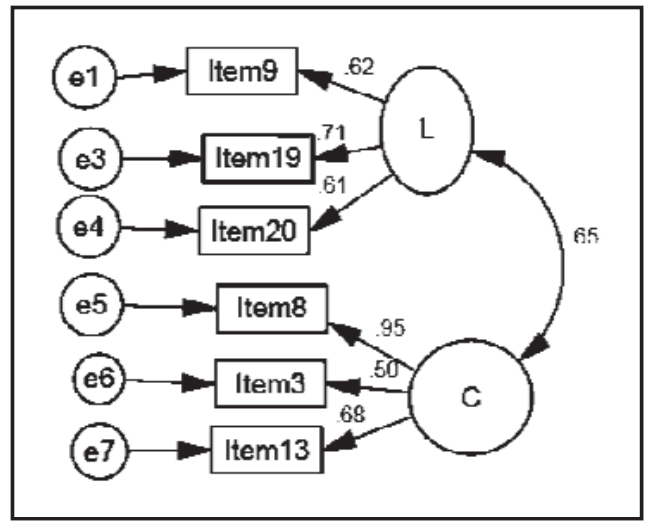

Figure 2: Model re-specified

Once re-specified model, we proceeded to evaluate that there were no offending estimates. In Table 3, the weight of each of the indicators that compose each construct is shown. It can be observed that none of the standardized coefficients has exceeded or are close to 1 . Moreover, the measurement error values for all the indicators are positive, as illustrated in Table 3.1

Table 3. Weighting of constructs

\begin{tabular}{lcc}
\hline & Likeness & Confidence \\
\hline Variable & Ítem 20 & Ítem 13 \\
Weighting & 0.627 & 0.695 \\
Significance & & \\
Variable & Ítem 19 & Ítem 3 \\
Weighting & 0.805 & 0.516 \\
& & \\
& &
\end{tabular}




\begin{tabular}{llc} 
Significance & 6.563 & 8.553 \\
Variable & Ítem 9 & Ítem 8 \\
Weighting & 0.640 & 0.923 \\
Significance & 4.720 & 10.800 \\
\hline
\end{tabular}

Source: own

Table 3.1: Measurement error for the indicators

\begin{tabular}{ccccccc}
\hline Item & 20 & 19 & 9 & 13 & 3 & 8 \\
\hline 20 & 0.607 & & & & & \\
19 & 0.000 & 0.313 & & & & \\
9 & 0.000 & 0.000 & 0.614 & & & \\
13 & 0.000 & 0.000 & 0.000 & 0.534 & & \\
3 & 0.000 & 0.000 & 0.000 & 0.000 & 0.740 & \\
8 & 0.000 & 0.000 & 0.000 & 0.000 & 0.000 & 0.118 \\
\hline
\end{tabular}

Source: own

Regarding the correlations between constructs --the values obtained-- none have values greater than 1.0 (Table 4), at the same time, we can see a close association between the constructs: likeness, and confidence.

Table 4: Correlations among latent constructs

\begin{tabular}{ccc}
\hline & Likeness & Confidence \\
Likeness & 1 & 0.584 \\
Confidence & & 1 \\
\hline
\end{tabular}

Source: own

Global adjusted of model. Table 5 provides the quality measures of absolute fit. The chi-square statistic $(15.123, \mathrm{df}=8$, sig $=0.057)$ show a satisfactory fit. The values of GFI (0.985), AGFI (0.960) and RMSA (.052) are satisfactory because their values tend to 1 and are $>$ of .5 .

Table 5. Measures Goodness of Fit: Revised model and null

\begin{tabular}{lc}
\hline Chi-square $\left(X^{2}\right)$ & 15.123 \\
Degree of freedom (df) & 8.0 \\
Significance level (sig.) & 0.057 \\
Normed Chi-square $\left(X^{2} / g l\right)$ & 1.890 \\
Goodness of Fit Index (GFI) & 0.985 \\
Adjusted Goodness of Fit Index (AGFI) & 0.960 \\
Root Mean Square Error of Approximation (RMSEA) & 0.052 \\
Tucker Lewis Index (TLI) & 0.974 \\
Normed Fit Index (NFI) & 0.972 \\
\hline
\end{tabular}

Source: own

Upon acceptance the model (as a set), were evaluated each of the constructs in order to check the internal consistency of all indicators to measure the concept. The results in Table 6 indicate that the reliability values related to the constructs range from 0.536 onwards (>), it means, that not all indicators are consistent with its measure.

The table shows also, extracted variance, which must be higher 0.50 in this case, the values of one of the construct are below 0.5 (motivation) which means, that more than half of the variance of the indicators is not taken into account for the construct.

Also confidence and pleasant constructs are very close to 0.500 , which is a recommended value for the average 
variance extracted (Fornell and Larcker, 1981, cited by Calvo de Mora and Criado, 2005

Table 6. Reliability and variance of constructs

\begin{tabular}{ccc}
\hline Indicators & Reliability & Extracted means variance \\
\hline Likeness & 0.824 & 0.614 \\
Confidence & 0.765 & 0.536 \\
\hline
\end{tabular}

Source: own

Regarding discriminant validity, the values showed in Table 7 reveal that all are less than 1 ; it means, that none of the items that were part of the different factors, shown in the other constructs.

Table 7. Discriminant Validity

\begin{tabular}{ccc}
\hline & Likeness & Confidence \\
\hline Likeness & $\mathbf{0 . 7 3 2 1}$ & 0.653 \\
Confidence & & $\mathbf{0 . 7 8 3 9}$ \\
\hline
\end{tabular}

Source: own

Once proved reliability, variance extracted and discriminant validity, we proceed to compare the model results and the model 2.

When comparing the results of model 1 and model 2, we can see that the value of Chi-square $\left(\mathrm{X}^{2}\right)$ decreased from 1880.078 to 15.123 and the value of RMSEA decrease of 0.193 to 0.052 , while the goodness of fit indexes GFI and AGFI improved from 0.677 to 0.985 and from 0.574 to 0.960 respectively. In the same way, the incremental fit measures (TLI and $\mathrm{NFI}$ ) have enriched and exceed the recommended level of 0.90 . Siendo este último modelo el que mejor se ajusta a los datos.

\section{Concluding Remark}

The theoretical model formulated tries to show that: likeness, anxiety, confidence, motivation, usefulness have influence on students' attitude toward statistic. However, the result show evidence that data analysis only fit to the components: likeness and confidence.

Of 25 proposed indicators only 6 of them have an acceptable range, that is, the students' attitude towards statistics in the Universidad Politécnica is a friendly attitude (cordially), which reveals that, at this Institution the subject matter Statistics is focused on the application practice and thus, will not cause anxiety and does not require students motivate to their learning, because to make practical use of it, this will generate a sensation of likeness (pleasure) and consequently the student gains confidence towards it.

Finally as a suggestion, it is advisable to review the content of the curriculum of Statistical Programs of the institution and verify the approach that is given, verifying that the approach is as was suggested above mentioned, i.e., the practical application given to the statistics which helps to make the student does not show traits of anxiety, then recommend to the institutions of higher education, to give this approach to the field of statistics, considering this empirical result.

\section{Acknowledges}

The authors are very grateful to the anonymous blind-reviewer for all suggestions, to the Cristobal Colon University and Universidad Politécnica for all helping and support.

\section{References}

Auzmendi, E. (1992). Evaluación de las actitudes hacia la estadística en alumnos universitarios y factores que las determinan. [Evaluation of attitudes towards statistics in college students and factors which determine them] Unpublished doctoral thesis: 
Universidad de Deusto, Bilbao.

Beins, B.C. (1985). Teaching the relevance of statistics trough consumer-oriented research. Teaching of Psychology,12, 168-169

Blanco, A. (2008). Una revisión crítica de la investigación sobre las actitudes de los estudiantes universitarios hacia la Estadística. [A critical review of research on the college students' attitudes towards statistics] Revista Complutense de Educación 19 (2), 311 330.

Browne, M. W. and Cudeck, R. (1993). Alternative ways of assessing model fit. Newbury Park: Sage Publications.

Calvo de Mora and Criado (2005). Análisis de la validez del modelo europeo de excelencia para la gestión de la calidad en las Instituciones universitarias: un enfoque directivo. [Analysis of the validity of the European model of excellence for the quality management in the university institutions: a directive approach] Revista Europea de Dirección y Economía de la Empresa, vol 14, num. 3 pp 41-58 ISSN 1019-6838

Chang, L. (1996), 'Quantitative attitudes questionnaire: instrument development and validation', Educational and Psychological Measurement 56(6), 1037-1042

Chin, W. W. and Todd, P. A. (1995). On the use, usefulness and ease of structural equation modeling in mis research: A note of caution. MIS quarterly, 19(2), 237-247. command language. Hillsdale, NJ: Lawrence Erlbaum Associates. confirmatory factor analysis. MIS quarterly, 17(4), 517-525. Edition ed.). Englewood Cliffs, New Jersey: Printice-Hall Inc.

Elmore, P.B. and Lewis, E.L. (1991). Statistics and computer attitudes and achievement of students enrolled in applied statistrics: Effect of a Computer laboratory. Chicago: American Educational Research Association Annual Meeting.

Evans, B. (2007). Student Attitude, Conceptions and Achievement in Introductory Undergraduate College Statistics. The Mathematics Educator, 17(2), 24-30.

Gal, I. y Ginsburg, L. (1994): The Role of Beliefs and Attitudes in Learning Statistics: Towards an Assesment Framework. Journal of Statistics Education, 2 (2) Obtained of: http://www.amstat.org/publications/jse/v2n2/gal.html.

García-Santillán, A.; Venegas-Martínez, F.; Escalera-Chávez, M.; Córdova-Rangel, A. (2013). Attitude towards statistics in engineering college: An empirical study in public university (UPA). Journal of Statistical and Econometric Methods Vol. 2 Issue 1, 3 March pp 43-60

García-Santillán, A.; Venegas-Martínez, F.; Escalera-Chávez, M.; (2013). An exploratory factorial analysis to measure attitude toward statistic: Empirical study in undergraduate students. International Journal of Research and Reviews in Applied Sciences Vol 14, issue 2 february 2013 pp 356-366

García-Santillán, A; Escalera-Chávez, M; and Córdova Rangel, A: (2012). Variables to measure interaction among mathematics and computer through structural equation modeling. Journal of Applied Mathematics and Bioinformatics Vol 2, No. 3 pp 51-67

García-Santillán, A.; Moreno, E.; Carlos, J.; Zamudio, J. \& Garduño, J. (2012). Cognitive, Affective and Behavioral Components that explain Attitude toward Statistics. Journal of Mathematics Research. Vol 4, No. 5, October 2012 pp 8-16. http://dx.doi.org/10.5539/jmr.v4n5p8

Gefen, D. Straub, D. W. and Boudreau, M. (2000). Structural equation modelling and regression: Guidelines for research practice. Communications of the Association for Information Systems (AIS), 4(7).

Gil, J. (1999). Actitudes hacia la estadística. Incidencia de las variables sexo y formación previa [Incidence of the variables sex and previous training]. Revista Española de Pedagogía, 57( 214), 567-590.

Ginsburg, L. y Schau, C. (1997). Monitoring Attitudes and Beliefs in Statistics Education. En Gal, I. y Garfield, J. (Eds.)(1997). The Assessment Challenge in Statistics Education. Amsterdam, IOS Press and International Statistical Institute.

Glencross, M. J., y Cherian, V. J. (1992). Attitudes toward applied statistics of postgraduate education students in Transkei. Psychological Reports, 70, 67-75.

Hair, J. F. Anderson, R. E. Tatham, R. L. and Black, W. C. (1998). Multivariate data analysis (Fifth edition. Spain Prentice Hall.

Joreskog, K. G. and Sorbom, D. (1993). Liseral8: Structural equation modeling with the SIMPLIS command language. Hillsdale, NJ: Lawrence Erlbaum Associates.

Katz, B. M. y Tomazic, T.C. (1988). Changing student's attitude toward statistics through a nonquatitative approach. Psichological Reports, 62, 658.

Mondéjar, J., Vargas, M., \& Bayot, A. (2008). Measuring attitude toward statistics: the influence of study processes. Electronic Journal of Research in Educational Psychology, 16 (3), 729-748.

Phillips, J.L. (1980): La lógica del pensamiento estadístico.[The logic of statistical thought] México, el Manual Moderno.

Roberts, D.M. and Bilderback, E.M. (1980). Realibility and Validity of a "Statistics Attitude Survey". Educational and Psychological Measurement, 40, 235-238.

Roberts, D.M. y Saxe, J.E. (1982). Validity of Statistics Attitude Survey: A Follow-Up Stuty. Educational and Psychological Measurement, 42, 907-912.

Sánchez-López, C.R. (1996). Validación y análisis ipsativo de la Escala de Actitudes hacia la Estadística (EAE). [ Validity and ipsative analysis of scale attitude toward statistic] Análisis y modificación de conducta, 22, 799-819.

Schau, C., Stevens, J., Dauphinee, T.L. and Del Vecchio, A. (1995). The development and validation of the Survey Attitudes Toward Statistics. Educational and Psychological Measurement, 55(5), 868-875.

Schutz, P.A., Drogosz, L.M., White, V. E. and C. Diestefano: Prior Knowledge, Attitude and Strategy Use in an Introduction to Statistics Course. Paper presented at the Annual Meeting of the American Educational Research Association, Chicago (1997).

Segars, A. H. and Grover, V. (1993). Re-examining perceived ease of use and usefulness: A confirmatory factor analysis. MIS quarterly, $17(4), 517-525$. 
Sutarso, T. (1992, November). Students' Attitudes Toward Statistics (STATS). Paper presented at the Mid-South Educational Research Association, Knoxville, TN.

Thompson, B. (2004). Exploratory and confirmatory factor analysis. Washington DC: American Psychological Association

Vanhoof, S., Castro, A.E., Onghena, P., Verschaffel, L., Van Dooren, W y Van Den Noortgate, W. (2006). Attitudes toward statistics and their relationship with short- and long-term exam results Journal of Statistics Education, 14(3).

Wise, S.L. (1985). The development and validation of a scale measuring attitudes toward statistics. Educational and Psychological Measurement, 45, 401-405.

Woehlke, P.L. (1991). An examination of the factor structure of Wise's Attitude Toward Statistics scale. Annual Meeting of the American Educational Research Association, Chicago, IL, USA. (ERIC Document Repro).

Zeidner, M. (1991). Statistics and mathematics anxiety in social science students: Some interesting parallels. British Journal of Educational Psychology, 61, 319-332. 
